\title{
4- Öğrenci metinleriyle yürütülen çalışmaların metinsellik açısından incelemesi
}

Mustafa CEYLAN'

APA: Ceylan, M. (2021). Öğrenci metinleriyle yürütülen çalışmaların metinsellik açısından incelemesi. RumeliDE Dil ve Edebiyat Araştırmaları Dergisi, (25), 56-70. DOI: 10.29000/rumelide.1032365.

$\ddot{O} \mathbf{z}$

Dil becerilerini kullanmanın en etkili ve kalıcı yolu yazılı anlatımdır. Yazılı anlatım sürecinde elde edilen tüm ürünler metin olarak kabul edilmemekte ve bulundurması gereken bazı özellikler vardır. Metinsellik öğeleri yazılı bir ürünün metin olarak nitelendirmesini sağlayan özelliklerden biridir. Bu çalışmanın amacı, öğrencilerin yazılı anlatım ürünlerini metinsellik öğeleri bakımından inceleyen araştırmalara yönelik bir literatür taraması oluşturmaktır. Metinsellik ölçütleri ile yapılan çalışmaların çoğunun basılmış eserler üzerinde yapılmış olması öğrencilerin yazılı ürünlerindeki metinsellik beceri düzeylerine karşı bir merak oluşturmuştur. Çalışmanın ilk aşamasında "Metinsellik”, "Bağdaşıklık”, “Tutarlılık”, “Amaçlılık”, "Kabul Edilebilirlik”, "Bilgilendiricilik”, "Duruma Uygun Olma” ve "Metinler Arasıllk anahtar sözcükleri belirlenmiştir. Anahtar sözcükler kullanılarak "Ulakbim, Google akademik, Eric, EBSCHost, Sage ve Web of Science” veri tabanları taranmıştır. Taramalar sonucunda elde edilen 74 araştırma dâhil edilme ölçütlerini karşılamaları bakımından incelenmiş ve ölçütleri karşılayan 20 araştırma içerik analizi yöntemi ile incelenmiştir. Çalışma sonunda, yaklaşık 29 yıl boyunca çeşitli araştırmaların yapıldığı ve 2011 yılından sonra bu alanda yapılan çalışmaların sıklaştığı, araştırmalarda araştırma yaklaşımlarından nicel yöntemin daha fazla kullanıldı̆̆ı, metinsellik öğelerinden en sık bağdaşıklık ve tutarlılık öğelerinin çalışıldı̆̆ı, katılımcıları açısından bakıldığında en fazla çalışmanın ortaokul ve lisans öğrencileri ile yürütüldüğü ve çoğunlukla sınıflar arasında metinsellik öğelerinin kullanım sıklıklarının karşılaştırıldığı bulguları elde edilmiştir. Elde edilen bulgular alan yazın çerçevesinde yorumlanarak tartışılmış ve deneysel çalışmalara ihtiyaç duyulduğu, ilkokul dönemindeki çalışmalara ağırlık verilmesi gerektiği, ayrıca bağdaşıklık ve tutarlılık öğeleri dışındaki metinsellik ölçütlerine de çalışmalarda yer verilmesi gerektiğine sonuçlarına yer verilmiştir.

Anahtar kelimeler: Metinsellik, yazılı anlatım, bağdaşıklık, tutarlılık, metinlerarasılık

\section{A text analysis of the studies conducted with student texts}

\begin{abstract}
The most effective and permanent way to use language skills is written expression. All products obtained in the written expression process are not accepted as texts and there are some features that they should have. Textuality is one of the features that make a written product qualify as text. The aim of this study is to create a literature review for studies that examine students' written expression products in terms of textuality. The fact that most of the studies with the textuality criteria were done on the printed works created a curiosity about the textuality skill levels of the written products of the students. In the first stage of the study, the keywords "Textuality", "Coherence", "Consistency", "Purposeness", “Acceptability”, "Informativeness", "Relevance to the Situation” and "Intertextuality"
\end{abstract}

Dr. Arş. Gör., Artvin Çoruh Üniversitesi, Eğitim Fakültesi, Özel Eğitim Bölümü (Artvin, Türkiye), mceylan@artvin.edu.tr, ORCID ID: 0000-0003-1922-0161 [Araştırma makalesi, Makale kayıt tarihi: 06.10.2021-kabul tarihi: 20.11.2021; DOI: $10.29000 /$ rumelide.1032365]

Adres
RumeliDE Dil ve Edebiyat Araştırmaları Dergisi Osmanağa Mahallesi, Mürver Çiçeği Sokak, No:14/8 Kadıköy - ISTANBUL / TÜRKIYE 34714 e-posta: editor@rumelide.com tel: +90 $5057958124,+902167730616$
Address

RumeliDE Journal of Language and Literature Studies

Osmanağa Mahallesi, Mürver Çiçeği Sokak, No:14/8

Kadıköy - ISTANBUL / TURKEY 34714

e-mail: editor@rumelide.com,

phone: +90 5057958124 , +90 2167730616 
were determined. "Ulakbim, Google academic, Eric, EBSCHost, Sage and Web of Science" databases were searched using keywords. 74 studies obtained as a result of the scans were examined in terms of meeting the inclusion criteria, and 20 studies that met the criteria were examined with the content analysis method. At the end of the study, it was concluded that various researches were conducted for about 29 years, studies in this field became more frequent after 2011, quantitative method was used more than research approaches, cohesion and coherence items were studied most frequently among the textuality items. The findings of the study were carried out and the frequency of use of textuality items was mostly compared between classes. The findings were interpreted and discussed within the framework of the literature, and it was concluded that experimental studies are needed, that studies in the primary school period should be emphasized, and that textuality criteria other than cohesion and coherence should be included in the studies.

Keywords: Textuality, written expression, cohesion, coherence, intertextuality

\section{Giriş}

Günümüzde iletişim ve dil becerilerinin önemi gittikçe artmaktadır, yazı da icat edildiği günden itibaren gittikçe güçlenen bir iletişim aracıdır. Yazılı anlatım becerisi, dil becerileri içerisinde konuşmadan daha sonra gelişmektedir. Yazının alanyazındaki geçmişi incelendiğinde konuşma becerisinden daha önceki tarihlerde de var olduğu görülmektedir. Bu bulguların konuşmanın kalıcı olmamasından kaynaklandığı düşünülmekle birlikte yazının, konuşma becerisinin aksine kalıcı olmasından dolayı tarihin başlangıcı olarak kabul edilmektedir. Çağımızda teknolojinin gelişmesi ile yazılı anlatımın konuşma becerisine olan üstünlüğü daha fazla hissedilebilmektedir. Son yıllarda milyarlarca internet kullanıcısı olduğu ve yine milyarca web sayfasının ziyaret edildiği düşünüldüğünde, yazılı anlatım becerisinin ne denli önemli olduğu daha iyi anlaşılmaktadır (Beyreli, Çetindağ ve Çelepoğlu, 2005, s. 36).

İnsanlar duygu, düşünce ve beklentilerini diğerlerine aktarabilmek isterler, bakıldığında kendini ifade edebilme becerisi toplumların temel ihtiyacıdır ve bunun içinde dil becerilerine gereksinim duyarlar (Berninger ve Abbott, 2010). Bu nedenle ulusal ve uluslararası alan yazında bireylerin kendini ifade edebilme becerisi üzerinde önemle durulan bir konudur (Yllmaz, 2012). Dil becerilerini kullanmanın en etkili ve kalıcı yolu yazılı anlatımdır.

Yazma becerisi; kişinin algıladığı dünyayı ifade etmeye çalışması, kafasındaki soyut kavramları harfler vasıtasıyla ete kemiğe bürüyerek somutlaştırma çabasıdır. Bu somutlaştırma çabası kişiden kişiye göre farklılaşır. Bazı öğrenciler duygu, düşünce ve bilgilerini yazıya uygun içerikte, düzende ve şekilde dökmekte zorlanırlar (Westwood, 2008). Bu durumun birçok nedeni vardır. Kişinin yetiştiği çevre, bireysel farklılıklar, aldığı eğitim bu nedenlerden birkaçıdır (Senechall, Hill ve Malette, 2018). Yazma eğitimi ile ilgili yapılan çalışmaların geneline bakıldığında bu becerinin aynı ölçülerde olmasa da herkese öğretilebileceği sonucuna ulaşılır (Çoban, 2012). Aynı düzeyde olmasa da, her birey yazılı üretimler meydana getirir. Dolayısıyla da metin, bireylerin kendilerini ifade etmelerine olanak sağlayan yöntemlerden biridir.

\section{Metin}

Metin her ne kadar sözcük ve tümcelerin bir araya gelmesiyle oluşuyor görünse de aslında metin kendini oluşturan sözcük ve tümceler toplamından çok daha farkl, kendine has bir yapıya sahiptir (Haliday ve Hasan, 1976; Güven, 2014). Oluşturulan metinler metin yazarının yaşına, birikim seviyesine, kendini

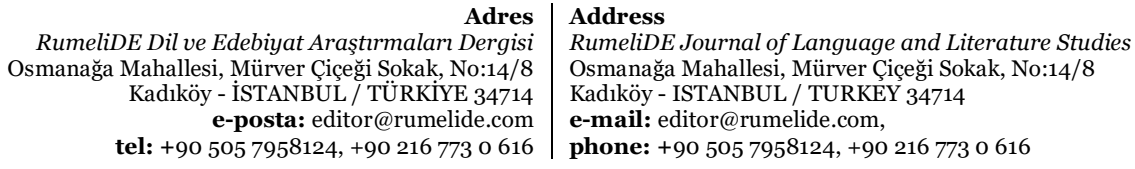


geliştirmiş olma düzeyine, sahip olduğu kelime hazinesi düzeyine ve buna benzer farklı niteliklere bağlı olarak değişiklik gösterir.

Bir metnin oluşturulması için bir takım süreçlerden geçmesi gerekmektedir. Metin, sözcük ve cümleleri barındıran basit bir yapı değil, onlar aracılığıyla oluşan bir bütündür (Haliday ve Hasan, 1976; Bae, 2001; Güven, 2014). Metin oluşturma iç içe geçmiş bir süreç olarak ilerler ve bu süreçte belirli aşamalardan geçilerek ortaya çıkar (Tok ve Gönülal, 2014). Öncelikle konu belirlenerek, üzerinde düşünülerek ve ifade etme yöntemine karar verilir. Ardından oluşturulan taslak metin ortaya çıar ve kontrol edilir. Yapılan kontrollerde gözlenen hatalar belirlenir ve bunlarla ilgili düzeltmeler yapılarak son hali verilir (Dağaşan, 2018). Cümlelerin ve sözcüklerin dilbilgisi kurallarına göre değerlendirilmesinde olduğu gibi, metinlerinde uygunluğunu değerlendirmede kullanılan çeşitli metinsellik ölçütleri bulunmaktadır (Günay, 2003; Lüleci, 2010; Karaağaç, 2013).

\section{Metinsellik ölçütleri}

Tüm yazarlar yazılı ürünlerinin nitelikli olması için çaba harcasalar da, ortaya çıkan tüm metinler maalesef nitelikli değildir. Metinlerin nitelikli olarak adlandırılması için bulundurmaları gereken bazı ölçütler bulunmaktadır. De Beaugrande ve Dressler (1981) bir yazılı ürünün metin sayılabilmesi gereken ölçütleri yedi kategoride değerlendirmiştir;

1. Bağdaşıklık: metni oluşturan birimler arasındaki anlam bütünlüğünü ve sözcükler arasındaki geçişleri sağlayan öğelerdir. Metnin tamamındaki anlamın anlaşılması ve yorumlanması işlemi; cümlelerin ve paragrafların hem kendi içlerinde hem de aralarında oluşmaktadır (Coşkun, 2005; Can, 2012; Yılmaz, 2012; Dağaşan, 2018).

2. Tutarlılık: anlam ve mantık bütünlüğ̈̈; anlatım planı, yazılı ürünlerde ele alına konunun anlam olarak ortaya çıkardığı ana düşünce açısından metnin tamamında bulunması gereken ilişki ve bağlantıdır. Metni meydana getiren sözcük, cümle ve paragraflar arasındaki konu ve ana düşünceyi barındıran anlatım yöntemindeki anlam bütünlüğü olarak da adlandırılabilir (Coşkun, 2005; Karatay, 2010; Yılmaz, 2012; Dağaşan, 2018).

3.Amaçlılık: yazar tarafinın oluşturulan metnin belirli bir amaca hizmet etmesidir. Her yazılı ürün belli bir amaca hizmet eder, metin yazarın amacını ne kadar barındırabilirse, yani okura ne kadarın ulaştırabilirse o kadar nitelikli kabul edilmektedir (Coşkun, 2005; Karatay, 2010; Yılmaz, 2012; Dağaşan, 2018).

4.Kabul edilebilirlik: metnin ana fikrinin aktarılmasının ardından bu düşüncenin okurlara en uygun şekilde, açık ve kanıtlanabilir olarak sunulmasıdır. Bir metnin kabul edilebilirliği amaçlılık ile doğru orantılıdır, bir metnin amaçları ne kadar net ortaya konulursa okurlar tarafından kabul edilebilirliği de o kadar yüksek olmaktadır (Coşkun, 2005; Karatay, 2010; Yllmaz, 2012; Dağaşan, 2018).

5.Bilgilendiricilik: metinde okurun eski bilgilerini hatırlamasını ve yeni bilgiler edinmesini sağlanmasıdır. Eski bilgilerin fazla olması metnin anlaşılabilirliğini arttırsa da okunmaya değer görülmemesine neden olabilir. Aynı şekilde yeni bilgilerin fazla olması ise okurun anlamamasını ve metinden sıkılmasına neden olabilir. Nitelikli bir metnin eski ve yeni bilgileri harmanlayarak sunması ve dengeli olması gerekmektedir (Coşkun, 2005; Can, 2012; Yılmaz, 2012).

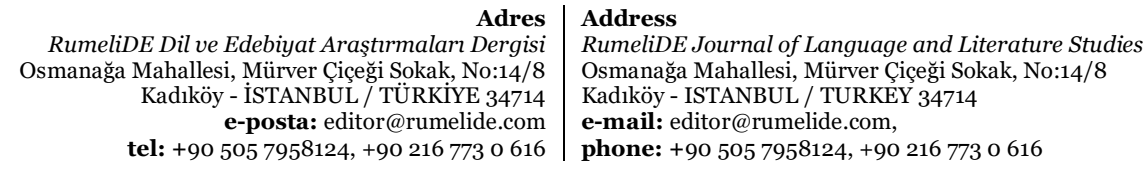


6.Duruma Uygun Olma: metnin ana fikrine, okuyucu kitlesine, amacına ve türüne uygun olmasını belirtmektedir. Kısa bir sürede anlaşılması istenen bir bilgi için çok uzun bir metin oluşturulursa bu duruma uygun olmaz. Hedef kitleye, ulaşılmak istenen amaca uygun hazırlanmayan metinlerin iletisi hedeflenen alıcıya ulaşmaz ya da ulaşması gecikir (Coşkun, 2005; Can, 2012; Yılmaz, 2012).

7.Metinler Arasılık: mevcut metnin diğer metinlerle var olan ilişkilerini ifade etmektedir. Hiçbir metin diğer metinlerden soyutlanmış olarak oluşturmamıştır, her metin diğer metinlerle gerek gönderim yoluyla gerekse devamı niteliğinde olarak ilişki içerisindedir. (Coşkun, 2005; Can, 2012; Yılmaz, 2012).

Metinlerde bulunması ölçütlerin incelendiği pek çok çalışma bulunmaktadır. Alanyazına bakıldığında yazılı ürünlerin metinsellik ölçütlerine göre değerlendirilmesi iki farklı şekilde yapılmaktadır. Birincisinde, ünlü yazarlar/uzmanlar tarafından yazılan metinlerin incelendiği çalışmalar (Akçay ve Şahin, 2015; Karakuş, Deniz ve Karayazı,2018; Bozok, 2019; Aksu, 2020) yer almaktadır. İkincinsinde ise öğrencilerin var olan yazma performanslarının metinsellik ölçütlerine göre değerlendirildiği ya da metinsellik ölçütlerinden bazılarının öğretimine yönelik uygulamaların yer aldığı çalışmalar (Keçik, 1992; Coşkun, 2008; Keklik ve Yılmaz, 2013; Seçkin Arslan ve Ergenç, 2014; Tok ve Gönülal, 2014; Sümer ve Turna, 2019; Aslan ve Çakmak, 2020) yer almaktadır. Alanyazındaki çalışmalardan elde edilen ortak bulgulara bakıldığında öğrenci metinlerindeki metinsellik ölçütlerinin pek çoğuna yer verilmediği, öğrencilerin yazılı ürünlerinin metinsellik boyutunda çok zorlandıklarını ve yazma becerisinin öğrencilerin gelişimleriyle artma gösterdiği görülmektedir (Coşkun, 2005; Aslan ve Çakmak, 2020).

Öğrenciler tarafından oluşturulan yazılı anlatım ürünlerinin metinsellik özelliklerinin edinilmesi, öğrencilerin iletişim aracı olarak kullanılan yazılı anlatım ürünü ortaya koyma becerileri düzeylerini belirlemek açısından son derece önemlidir. Ayrıca ilerleyen zamanlarda öğrencilere metinsellik ölçütleri bağlamında yazılı ürün oluşturmaları konusunda yardımcı olacağı için de önem taşımaktadır. Yine alanyazında metinsellik alanında öğrencilerin yazılı ürünlerinin incelendiği araştırmaların bir arada sunulduğu, derleme bir çalışmaya rastlanılmamıştır. Bu bakış açısıyla, gerçekleştirilmiş literatür taramasında ülkemizde öğrencilerin yazılı ürünlerinin metinsel açıdan değerlendiren çalışmaların incelenmesi amaçlanmıştır.

\section{Yöntem}

\section{Araştırma modeli}

Bu çalışmada içerik analizi, yöntemi kullanılmıştır. İçerik analizi, benzer yönleri olan verilerin belirli kavramlar ve ölçütler çerçevesinde bir araya getirilmesi ve yorumlanmasıdır (Yıldırım ve Şimşek, 2011). İçerik analizi meta-analiz, meta-sentez ve betimsel içerik analizi olmak üzere üçe ayrılmaktadır. Bu çalışmada, öğrenciler tarafından yazılmış metinler üzerinde yapılan metinsellik çalışmaları hakkında bilgi verildiği için betimsel içerik analizi kullanılmıştır. Betimsel içerik analizi; bir konu hakkında yapılan araştırmaların sonuçlarının tanımlayıcı bir boyutta değerlendirilmesine yönelik sistematik bir yöntem olarak tanımlanmaktadır (Çalık ve Sözbilir, 2014).

\section{Verilerin toplanması ve analizi}

Öğrencilerin yazılı ürünlerinde metinsellik çalışmalarının incelendiği bu çalışmada, verilerin toplanması için YÖK tez tarama merkezi, Ulakbim, Google akademik, Eric, EBSCHost, Sage ve Web of Science veritabanları taranmıştır. Tarama yapılırken anahtar sözcük olarak; "Metinsellik", "Bağdaşıklık”, "Tutarlılık”, “Amaçlılık”, "Kabul Edilebilirlik”, "Bilgilendiricilik”, "Duruma Uygun Olma”

Adres | Address

RumeliDE Dil ve Edebiyat Araştırmalar Dergisi $\quad$ RumeliDE Journal of Language and Literature Studies Osmanağa Mahallesi, Mürver Çiçeği Sokkak, No:14/8 $\quad$ Osmanağa Mahallesi, Mürver Çiçeği Sokak, No:14/8 Kadıköy - İSTANBUL / TÜRKIYE 34714 Kadıköy - ISTANBUL / TURKEY 34714 e-posta: editor@rumelide.com e-mail: editor@rumelide.com, tel: +90 505 7958124, +90 2167730616 phone: +90 505 7958124, +90 2167730616 
ve "Metinler Arasılık" kullanılmıştır. Ulaşılan çalışmalar doküman analizi ile yazarca aşağıda verilen ölçütlere göre incelenmiştir. Araştırmada incelenecek çalışmalar için belirlenen ölçütler şunlardır: a) Türkiye'de yapılmış olması, b) yazılı ürünler üzerinde yapılmalı, c) öğrencilerle yapılmış olmalı ve d) anahtar sözcüklerden en az birini barındırmalıdır.

Bilgisayar ortamında yazarın yapmış olduğu taramadan elde edilen araştırmalar ölçütler bağlamında incelendiğinde 20 araştırma çalışmaya dâhil edilmiştir. Çalışmaya dâhil edilmeyen 74 araştırma ise belirlenen ölçütleri karşllamamışlardır. Mevcut olan durumu ortaya koymak amacıyla nitel veri toplama tekniklerinin kullanıldığı araştırma yöntemleri nitel araştırmalar, nicel veri toplama tekniklerinin kullanıldığı araştırmalar ise nicel araştırmalar olarak adlandırılmaktadır. Uygulanan herhangi bir müdahalenin etkisini inceleyen araştırmalar da deneysel araştırmalar olarak adlandırılmaktadır (Ylldırım ve Şimşek, 2011). Kategorilerin oluşturulmasının ardından araştırmalar yazarlar arasında paylaşılmış ve incelemeleri bireysel olarak yapılmıştır.

\section{Araştırmanın güvenirliği}

Çalışmanın objektif olmasını sağlamak amacıyla yazar tarafından bir kodlama listesi oluşturulmuştur. Kodlama listesinde araştırmaların, yöntemleri, hangi metinsellik öğelerinin incelendiği, katılımcıları, veri toplama araçları, amaçları ve sonuçlarına yer verilmiştir. İçerik analizi yapılan bu çalışmada güvenirliği sağlamak amacıyla verilerin \%35’i ( 5 araştırma) başka bir uzman tarafından bağımsız olarak incelenmiştir. Çalışmanın güvenirliğini hesaplamak için puanlayıcılar arası güvenirlik formülü ((Görüş birliği/Görüş birliği+Görüş ayrılı̆̆ı) X 100) kullanılmış ve güvenirlik \% 89-95 aralığında bulunmuştur (Frankel ve Devers, 2000; Yelboğa ve Tavşancll, 2010).

\section{Bulgular ve yorum}

Belirlenen ölçütler çerçevesinde yapılan taramalar sonucunda öğrencilerin yazılı ürünlerinde metinsellik çalışmalarının incelendiği bu çalışmada 1992-2020 yılları arasında yapılmış 22 araştırmaya ulaşılmış ancak iki çalışmanın tam metinlerine ulaşılamadığından çalışmaya dâhil edilmemiştir. 28 yılı kapsayan bu sürede yapılan araştırmaların sayıca az olması ve bu çalışmaların da 2011 yılından sonra artış olması ülkemizdeki öğrencilerle yapılmış metinsellik çalışmalarının ne düzeyde olduğunu nispeten göstermektedir. Çalışmaya dâhil edilen araştırmalara ilişkin bulgular Tablo 1'de verilmiştir. İncelenen çalışmaların araştırma yöntemlerine bakıldığında çoğunluğunun nicel araştırma yöntemleri ile yürütüldüğü $(n=12)$, ardından nitel araştırma yöntemlerinin $(n=7)$ slkça görüldüğü ve en az da karma yöntem araştırmasının $(\mathrm{n}=1)$ kullanıldığı görülmektedir. Nicel yöntem içerisinde yalnızca tarama modelinin, nitel yönteme bakıldığında doküman incelemesi ve eylem araştırmasının, karma yöntemde ise tarama ve doküman incelemesi modellerinin kullanıldığı görülmektedir.

İncelenen araştırmaların konularına göre dağılımlarına bakıldığında; en fazla bağdaşıklık öğeleri ile tutarlılı̆̆n birlikte incelendiği çalışmaların (Coşkun, 2005; Coşkun, 2011; Can, 2012; Yılmaz, 2012; Seçkin, Arslan ve Ergenç, 2014; Çoban ve Karadüz, 2015; Kall, 2016; Aslan ve Çakmak, 2020) olduğu, ardından öğrenci metinlerinin tutarlılığının değerlendirildiği çalışmaların (Çeçen, 2011; Ülper, 2011; Tok ve Gönülal, 2014; Çoban ve Karadüz, 2016; Dağaşan, 2018;) geldiği. Daha sonra da yalnızca bağdaşıklık öğelerinin incelendiği (Coşkun, 2011; Keçik, 1992 ve Sümer ve Turna, 2019), metinler arasılık öğesinin (Göçer, 2012; Güler, 2018; Tutkun, 2019) yalnızca bir çalışmada metinsellik öğelerinin tamamının incelendiği (Göçer, 2010) yer aldığı görülmektedir.

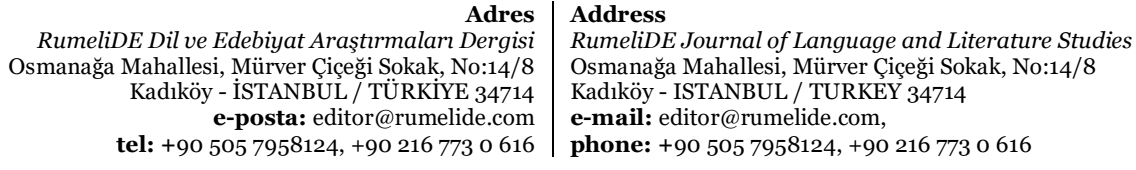


Araştırmaların amaçlarına göre dağılımlarına bakıldığında en fazla çeşitli sınıflar arasında bağdaşıklık ve tutarlılığa (Keçik, 1992; Coşkun, 2005; Ülper, 2011; Can, 2012; Seçkin, Arslan ve Ergenç, 2014; Çoban ve Karadüz, 2016; Kalı, 2016; Aslan ve Çakmak, 2020) karşılaştırmalar yapıldığı, ardından aynı sınıf düzeyinde çeşitli değişkenler çerçevesinde yazılı öğrenci ürünlerinin bağdaşıklık açısından incelendiği (Göçer, 2010; Coşkun, 2011; Göçer, 2012; Keklik ve Yılmaz, 2013; Çoban ve Karadüz, 2015; Sümer ve Turna, 2019) daha sonrada aynı sınıf düzeyinde çeşitli değişkenler çerçevesinde yazılı öğrenci ürünlerinin tutarlılık açısından incelendiği (Çeçen, 2011; Yılmaz, 2012; Tok ve Gönülal, 2014; Dağaşan, 2018) ve en az da aynı sınıf düzeyinde çeşitli değişkenler çerçevesinde yazılı öğrenci ürünlerinin metinlerarasılık açısından incelendiği (Güler, 2018; Tutkun, 2019) görülmektedir.

İncelenen araştırmaların örneklem gruplarına bakıldı̆̆ında en fazla ortaokul öğrencilerinin (Coşkun, 2005; Çeçen, 2011; Coşkun; 2011; Çoban ve Karadüz, 2015; Dağaşan, 2018; Güler, 2018; Sümer ve Turna, 2019; Tok ve Gönülal, 2014; Tutkun, 2019; Aslan ve Çakmak, 2020), ardından lise öğrencilerinin (Can, 2012; Yılmaz, 2012; Keklik ve Yllmaz, 2013), daha sonra lisans öğrencilerinin (Göçer, 2010; Ülper, 2011; Göçer, 2012; Seçkin, Arslan ve Ergenç, 2014; Çoban ve Karadüz, 2016; Kalı, 2016) ve en az da ilkokul öğrencilerinin (Keçik, 1922) yer aldığı görülmektedir.

Tablo 1. İncelenen Araştırmalara İlişkin Bulgular

\begin{tabular}{|c|c|c|c|c|c|c|c|}
\hline $\begin{array}{l}\text { Araştırmanı } \\
\text { n Adı }\end{array}$ & Yilı & Amaci & $\begin{array}{l}\text { Yönte } \\
\text { mi }\end{array}$ & $\begin{array}{l}\text { Örnekle } \\
\text { mi }\end{array}$ & $\begin{array}{l}\text { Katılimci } \\
\text { lar }\end{array}$ & $\begin{array}{l}\text { Veri } \\
\text { Toplama } \\
\text { Araci }\end{array}$ & Sonuç \\
\hline $\begin{array}{l}\text { İlkokul } \\
\text { öğrencilerinin } \\
\text { özet ve } \\
\text { hatırlama } \\
\text { metinlerinde } \\
\text { bağdaşıklık } \\
\text { sorunu }\end{array}$ & $\begin{array}{l}\text { Keçik, } \\
1992\end{array}$ & $\begin{array}{l}\text { İlkokul 2. ve } \\
5 . \text { sinıf } \\
\text { öğrencilerinin } \\
\text { ürettikleri } \\
\text { özet ve } \\
\text { hatırlama } \\
\text { metinleri } \\
\text { incelenerek } \\
\text { bu metinlerde } \\
\text { bağdaşıllığı } \\
\text { bozan } \\
\text { durumların } \\
\text { belirlenmesi }\end{array}$ & $\begin{array}{l}\text { Karma } \\
\text { yöntem }\end{array}$ & $\begin{array}{l}\text { 2. ve } 5 \text {. } \\
\text { sinıf } \\
\text { öğrenciler } \\
\text { i }\end{array}$ & $\begin{array}{l}\text { 2. sinıf } 144 \text {, } \\
\text { 5. Sinıf } 39 \\
\text { öğrenci }\end{array}$ & $\begin{array}{l}\text { Bilgilendi } \\
\text { rici } \\
\text { metinler }\end{array}$ & $\begin{array}{l}\text { Sinıflar arasında } \\
\text { anlamlı farklılık } \\
\text { olmamakla } \\
\text { birlikte her iki } \\
\text { sınıf seviyesinde } \\
\text { de öğrenciler } \\
\text { bağdaşılık } \\
\text { öğelerini } \\
\text { kullanamamakt } \\
\text { adır. }\end{array}$ \\
\hline $\begin{array}{l}\text { İlköğretim } \\
\text { öğrencilerinin } \\
\text { öyküleyici } \\
\text { anlatımlarınd } \\
\text { a bağdaşılılı, } \\
\text { tutarlılık ve } \\
\text { metin } \\
\text { elementleri }\end{array}$ & $\begin{array}{l}\text { Coşku } \\
\text { n, } \\
2005\end{array}$ & $\begin{array}{l}\text { 5. ve } 8 \text {. sınıfta } \\
372 \\
\text { öğrencinin } \\
\text { öyküleyici } \\
\text { anlatımları, } \\
\text { bağdaşıklı, } \\
\text { tutarlılık ve } \\
\text { metin } \\
\text { elementleri } \\
\text { açısından } \\
\text { değerlendiril } \\
\text { mesi }\end{array}$ & $\begin{array}{l}\text { Nicel } \\
\text { yöntem }\end{array}$ & $\begin{array}{l}5 . \text { ve } 8 . \\
\text { sinıf } \\
\text { öğrenciler } \\
\text { i }\end{array}$ & $\begin{array}{l}\text { 5. Sinif } 191 \text {, } \\
\text { 8. sinif } 181\end{array}$ & $\begin{array}{l}\text { Öğrenciler } \\
\text { in yazılı } \\
\text { ürünleri } \\
\text { (Konu } \\
\text { verilmiş) }\end{array}$ & $\begin{array}{l}\text { Bağdaşıklık, } \\
\text { tutarlılık ve } \\
\text { metin } \\
\text { elementleri } \\
\text { açısından sınıf } \\
\text { seviyesine göre } \\
\text { anlamlı farklılık } \\
\text { var. }\end{array}$ \\
\hline $\begin{array}{l}\text { Ĕ̆itim } \\
\text { fakültesi } \\
\text { öğrencilerinin } \\
\text { yazılı anlatım } \\
\text { becerilerinin } \\
\text { süreç } \\
\text { yaklaşımı ve } \\
\text { metinsellik } \\
\text { ölçütleri }\end{array}$ & $\begin{array}{l}\text { Göçer, } \\
2010\end{array}$ & $\begin{array}{l}\text { Eğitim } \\
\text { fakültesi } \\
\text { öğrencilerinin } \\
\text { yazılı anlatım } \\
\text { becerilerini } \\
\text { kullanma } \\
\text { durumlarını } \\
\text { belirlemek }\end{array}$ & $\begin{array}{l}\text { Nitel } \\
\text { yöntem }\end{array}$ & $\begin{array}{l}\text { Üniversit } \\
\text { e } 3 . \text { sinıf } \\
\text { öğrenciler } \\
\text { i }\end{array}$ & $\begin{array}{l}10 \\
\text { üniversite } \\
\text { 3. Sinıf } \\
\text { öğrencisi }\end{array}$ & $\begin{array}{l}\text { Öğrenciler } \\
\text { in yazıll } \\
\text { ürünleri } \\
\text { (Konu } \\
\text { verilmemi } \\
\text { ş) }\end{array}$ & $\begin{array}{l}\text { Öğrencilerin } \\
\text { yazmış olduğu } \\
\text { kompozisyonlar } \\
\text { metinsellik } \\
\text { ölçütlerine } \\
\text { kısmen sahip } \\
\text { olarak } \\
\text { nitelendirilmişti } \\
\text { r. }\end{array}$ \\
\hline & $\begin{array}{r}\text { RumeliDE } \\
\text { smanağa } \mathrm{M} \\
\mathrm{K} \\
\text { te }\end{array}$ & $\begin{array}{l}\text { il ve Edebiyat Araşt } \\
\text { allesi, Mürver Ciçeğ } \\
\text { dlköy - İSTANBUL / } \\
\text { e-posta: edito } \\
\text { +90 505 7958124, + }\end{array}$ & $\begin{array}{r}\text { Adres } \\
\text { malarl Dergisi } \\
\text { Sokak, No:14/8 } \\
\text { ÜRKIYE } 34714 \\
\text { Drumelide.com } \\
2167730616\end{array}$ & \multicolumn{4}{|c|}{\begin{tabular}{|l} 
Address \\
RumeliDE Journal of Language and Literature Studies \\
Osmanağa Mahallesi, Mürver Çiçeği Sokak, No:14/8 \\
Kadlköy - ISTANBUL/ TURKEY 34714 \\
e-mail: editor@rumelide.com, \\
phone: +90 505 7958124, +90 216773 o 616
\end{tabular}} \\
\hline
\end{tabular}


ekseninde değerlendiril mesi

\begin{tabular}{|c|c|c|c|c|c|c|c|}
\hline $\begin{array}{l}\text { Türk ve } \\
\text { göçmen } \\
\text { öğrencilerin } \\
\text { yazılı } \\
\text { anlatımlarınd } \\
\text { a metin } \\
\text { bağdaşıklığı }\end{array}$ & $\begin{array}{l}\text { Coşku } \\
\text { n, } \\
2011\end{array}$ & $\begin{array}{l}\text { Göçmen } \\
\text { öğrencilerle } \\
\text { Türk } \\
\text { öğrencilerin } \\
\text { yazdıkları } \\
\text { metinleri } \\
\text { bağdaşıklık } \\
\text { araçlarının } \\
\text { sıklığı } \\
\text { açısından } \\
\text { incelemek }\end{array}$ & $\begin{array}{l}\text { Nicel } \\
\text { yöntem }\end{array}$ & $\begin{array}{l}\text { 5. sinıf } \\
\text { öğrenciler } \\
\text { i }\end{array}$ & $\begin{array}{l}98 \\
\text { göçmen, } \\
103 \text { Türk }\end{array}$ & $\begin{array}{l}\text { Öğrenciler } \\
\text { in yazılı } \\
\text { ürünleri } \\
\text { (Konu } \\
\text { verilmiş) }\end{array}$ & $\begin{array}{l}\text { Eksiltili anlatım } \\
\text { dışındaki } \\
\text { bağdaşıklık } \\
\text { araçlarının } \\
\text { kullanım } \\
\text { sıklığında } \\
\text { göçmen ve Türk } \\
\text { öğrenciler } \\
\text { arasında } \\
\text { anlamlı fark } \\
\text { bulunamamıştır } \\
\text {. }\end{array}$ \\
\hline $\begin{array}{l}\text { Yedinci sınıf } \\
\text { öğrencilerinin } \\
\text { öyküleyici } \\
\text { yazılarında } \\
\text { tutarlılık }\end{array}$ & $\begin{array}{l}\text { Çeçen, } \\
2011\end{array}$ & $\begin{array}{l}7 \text { sınıf } \\
\text { öğrencilerinin } \\
\text { öyküleyici } \\
\text { yazılarının, } \\
\text { tutarlılık } \\
\text { açısından } \\
\text { değerlendirm } \\
\text { esi }\end{array}$ & $\begin{array}{l}\text { Nicel } \\
\text { yöntem }\end{array}$ & $\begin{array}{l}\text { 7. sinıf } \\
\text { öğrenciler } \\
\text { i }\end{array}$ & $\begin{array}{l}34 \text { yedinci } \\
\text { sinif }\end{array}$ & $\begin{array}{l}\text { Öğrenciler } \\
\text { in yazılı } \\
\text { ürünleri } \\
\text { (Konu } \\
\text { verilmiş) }\end{array}$ & $\begin{array}{l}\text { Tutarlılık puanı } \\
5 \text { üzerinden } 3,13 \\
\text { ve yazılan } \\
\text { metinler orta } \\
\text { seviyede tutarlı } \\
\text { bulunmuştur. }\end{array}$ \\
\hline
\end{tabular}

Tablo 1 devamı...

\begin{tabular}{|c|c|c|c|c|c|c|c|}
\hline $\begin{array}{l}\text { Araştırmanı } \\
\text { n Adı }\end{array}$ & Yilı & Amaci & $\begin{array}{l}\text { Yönte } \\
\text { mi }\end{array}$ & $\begin{array}{l}\text { Örnekle } \\
\text { mi }\end{array}$ & $\begin{array}{l}\text { Katılımes } \\
\text { lar }\end{array}$ & $\begin{array}{l}\text { Veri } \\
\text { Toplama } \\
\text { Araci }\end{array}$ & Sonuç \\
\hline $\begin{array}{l}\text { Öğrenci } \\
\text { metinlerinin } \\
\text { tutarlılık } \\
\text { ölçütleri } \\
\text { bağlamında } \\
\text { değerlendiril } \\
\text { mesi }\end{array}$ & $\begin{array}{l}\text { Ülper } \\
\text {, } 2011\end{array}$ & $\begin{array}{l}\text { Öğrencilerin } \\
\text { yazma } \\
\text { sorunlarının } \\
\text { tutarlılık } \\
\text { açısından yaş, } \\
\text { okul, cinsiyet } \\
\text { değişkenlerin } \\
\text { e göre } \\
\text { farklılaşıp } \\
\text { farklılaşmadığ } \\
\text { inı incelemek }\end{array}$ & $\begin{array}{l}\text { Nitel } \\
\text { yöntem }\end{array}$ & $\begin{array}{l}\text { 8., 12. ve } \\
\text { lisans } 4 \text {. } \\
\text { sinif }\end{array}$ & $\begin{array}{l}\text { 8. sinif } 35, \\
\text { 12. sinif } 24 \text {, } \\
\text { lisans } 4 \text {. } \\
\text { sinif } 33 \text { / } \\
49 \mathrm{kzz}, 43 \\
\text { erkek }\end{array}$ & $\begin{array}{l}\text { Öğrencile } \\
\text { rin } \\
\text { yazdıkları } \\
\text { denemele } \\
\mathrm{r}\end{array}$ & $\begin{array}{l}\text { Kızların ve } \\
\text { yüksek öğretim } \\
\text { öğrencilerinin } \\
\text { daha başarılı } \\
\text { oldukları } \\
\text { bulgulanmıştır. }\end{array}$ \\
\hline $\begin{array}{l}\text { Ortaöğretim } \\
\text { öğrencilerinin } \\
\text { yazılı } \\
\text { anlatımlarınd } \\
\text { a paragraf } \\
\text { düzeyinde } \\
\text { bağdaşıklık ve } \\
\text { tutarlılık }\end{array}$ & $\begin{array}{l}\text { Can, } \\
2012\end{array}$ & $\begin{array}{l}\text { Ortaöğretim } \\
\text { öğrencilerinin } \\
\text { yazılı } \\
\text { anlatımları } \\
\text { paragraf } \\
\text { düzeyinde } \\
\text { bağdaşıklık, } \\
\text { tutarlılık ve } \\
\text { düşünceyi } \\
\text { geliştirme } \\
\text { teknikleri } \\
\text { bakımından } \\
\text { değerlendiril } \\
\text { mesi }\end{array}$ & $\begin{array}{l}\text { Nicel } \\
\text { yöntem }\end{array}$ & $\begin{array}{l}\text { 9. ve } 10 . \\
\text { sinıf } \\
\text { öğrenciler } \\
\text { i }\end{array}$ & $\begin{array}{l}\text { 9. sinıf } \\
262,10 \text {. } \\
\text { sinıf } 262 \\
\text { öğrenci }\end{array}$ & $\begin{array}{l}\text { Öğrencile } \\
\text { rin yazılı } \\
\text { ürünleri } \\
\text { (Konu } \\
\text { verilmiş) }\end{array}$ & $\begin{array}{l}\text { Öğrencilerin } \\
\text { tutarlılık } \\
\text { puanlarında } \\
\text { anlamlı farklılık } \\
\text { görülmezken } \\
\text { diğer değişkenler } \\
\text { sinıf seviyesinde } \\
\text { karşılaştırılmamı } \\
\text { ştır. }\end{array}$ \\
\hline $\begin{array}{l}\text { Türkçe } \\
\text { Öğretmen } \\
\text { Adaylarının } \\
\text { Yetizleme } \\
\text { Çalışmalarıyla } \\
\text { Oluşturduklar } \\
\text { 1 Metinlerin }\end{array}$ & $\begin{array}{l}\text { Göçer } \\
\text {, } 2012\end{array}$ & $\begin{array}{l}\text { Türkçe } \\
\text { öğretmeni } \\
\text { adaylarının } \\
\text { yazma eğitimi } \\
\text { dersi } \\
\text { yetizleme } \\
\text { çalışmaları }\end{array}$ & $\begin{array}{l}\text { Nitel } \\
\text { Yöntem }\end{array}$ & $\begin{array}{l}\text { Üniversit } \\
\text { e } 3 . \text { sinıf } \\
\text { öğrenciler } \\
\text { i }\end{array}$ & $\begin{array}{l}12 \\
\text { üniversite } \\
\text { 3. sinıf } \\
\text { öğrencisi }\end{array}$ & $\begin{array}{l}\text { Öğrencile } \\
\text { rin yazıll } \\
\text { ürüleri } \\
\text { (Konu } \\
\text { verilmemi } \\
\text { ş) }\end{array}$ & $\begin{array}{l}\text { Türkçe öğretmen } \\
\text { adaylarının } \\
\text { yetizleme } \\
\text { çalışmalarıyla } \\
\text { ortaya } \\
\text { koydukları } \\
\text { metinlerin }\end{array}$ \\
\hline & $\begin{array}{r}\text { RumeliDE } \\
\text { smanağa } \mathrm{M} \\
\mathrm{K} \\
\text { tel }\end{array}$ & $\begin{array}{l}\text { Dil ve Edebiyat Araşt } \\
\text { hallesi, Mürver Ciçĕ } \\
\text { dıköy - İSTANBUL / } \\
\text { e-posta: edito } \\
\text { +90 } 5057958124,+\end{array}$ & $\begin{array}{r}\text { Adr } \\
\text { rmaları Derg } \\
\text { Sokak, No:14 } \\
\text { rÜRKIYE 347 } \\
\text { @rumelide.co } \\
\text { O } 216773 \text { o } 6\end{array}$ & \multicolumn{4}{|c|}{\begin{tabular}{|l} 
Address \\
RumeliDE Journal of Language and Literature Studies \\
Osmanağa Mahallesi, Mürver Ciçeği Sokak, No:14/8 \\
Kadkköy - ISTANBUL/ TURKEY 34714 \\
e-mail: editor@rumelide.com, \\
phone: +90 505 7958124, +90 216773 o 616
\end{tabular}} \\
\hline
\end{tabular}




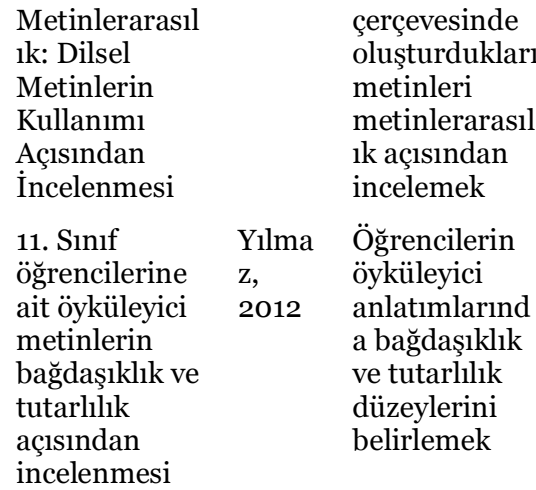

metinlerarasıllk ölçütünü karşılayan niteliklere sahip olduğu görülmüştür.

$\begin{array}{lll}\text { Nicel } & \text { 11. Sinıf } & 1240 \\ \text { yöntem } & \text { öğrenciler } & \begin{array}{l}\text { kadın, 1210 } \\ \text { erkek }\end{array} \\ & \text { i } & \end{array}$

Öğrencile Tutarlılıkta tüm rin yazılı değişkenlerde ürünleri farklılık vardır, (Konu ayrica verilmiş), bağdaşıklıkta yalnızca ailenin gelir düzeylerine farklılık bulunmamıştır.

Tablo 1 devami...

\begin{tabular}{|c|c|c|c|c|c|c|c|}
\hline $\begin{array}{l}\text { Araştırman } \\
\text { in Adı }\end{array}$ & Yilı & Amaci & $\begin{array}{l}\text { Yöntem } \\
\text { i }\end{array}$ & $\begin{array}{l}\text { Örnekle } \\
\text { mi }\end{array}$ & $\begin{array}{l}\text { Katılımci } \\
\text { lar }\end{array}$ & $\begin{array}{l}\text { Veri } \\
\text { Toplam } \\
\text { a Aracı }\end{array}$ & Sonuç \\
\hline $\begin{array}{l}\text { 11. Sinıf } \\
\text { öğrencilerine } \\
\text { ait öyküleyici } \\
\text { metinlerin } \\
\text { bağdaşıklık ve } \\
\text { tutarlılık } \\
\text { açısından } \\
\text { incelenmesi }\end{array}$ & $\begin{array}{l}\text { Keklik } \\
\text { ve } \\
\text { Yllmaz } \\
\text {, } 2013\end{array}$ & $\begin{array}{l}\text { 11. sınıf } \\
\text { öğrencilerin } \\
\text { in } \\
\text { öyküleyici } \\
\text { anlatımların } \\
\text { da } \\
\text { bağdaşıklık } \\
\text { ve tutarlılık } \\
\text { oluşturma } \\
\text { başarılarını } \\
\text { n hangi } \\
\text { düzeyde } \\
\text { olduğunu } \\
\text { belirlemekti } \\
\text { r. }\end{array}$ & $\begin{array}{l}\text { Nicel } \\
\text { yöntem }\end{array}$ & $\begin{array}{l}\text { 11. sinıf } \\
\text { ögrenciler } \\
\text { i }\end{array}$ & $\begin{array}{l}152 \text { kadın, } \\
148 \text { erkek }\end{array}$ & $\begin{array}{l}\text { Öğrencile } \\
\text { rin yazıll } \\
\text { ürünleri } \\
\text { (Konu } \\
\text { verilmiş) }\end{array}$ & $\begin{array}{l}\text { Bağlama ögeleri } \\
\text { 13,24 puan, } \\
\text { gönderim 11,67 } \\
\text { puan, eksiltili } \\
\text { anlatım 5,69 } \\
\text { puan ve } \\
\text { değiştirim 1,69 } \\
\text { puandır. } \\
\text { Ö̈ğrencilerin } \\
\text { tutarlılı puanı } \\
\text { ortalaması } 5 \\
\text { üzerinden 1,87 } \\
\text { puan olarak } \\
\text { bulunmuştur. }\end{array}$ \\
\hline $\begin{array}{l}\text { Bağdaşıklık } \\
\text { ve tutarlılık } \\
\text { bakımından } \\
\text { lise ve } \\
\text { üniversite } \\
\text { öğrencilerinin } \\
\text { yazılı anlatım } \\
\text { becerileri }\end{array}$ & $\begin{array}{l}\text { Seçkin, } \\
\text { Arslan } \\
\text { ve } \\
\text { Ergenç } \\
\text {, } 2014\end{array}$ & $\begin{array}{l}\text { Lise ve } \\
\text { üniversite } \\
\text { öğrencilerin } \\
\text { in yazılı } \\
\text { anlatımların } \\
\text { da } \\
\text { bağdaşıklık } \\
\text { unsurlarını } \\
\text { kullanımları } \\
\text { nı ve } \\
\text { tutarlılı } \\
\text { düzeylerini } \\
\text { belirlemekti } \\
\text { r. }\end{array}$ & $\begin{array}{l}\text { Nicel } \\
\text { yöntem }\end{array}$ & $\begin{array}{l}\text { 9.,11., } \\
\text { Lisans } 1 . \\
\text { ve Lisans } \\
\text { 3. Sinıf } \\
\text { öğrenciler } \\
\text { i }\end{array}$ & $\begin{array}{l}\text { 9. sinif 20, } \\
\text { 11. sinif, } \\
\text { 20, lisans } \\
\text { 1. Sinif } 20 \\
\text { ve lisans } 3 . \\
\text { sinif } 20 \text { / } \\
40 \text { kadin } \\
40 \text { erkek }\end{array}$ & $\begin{array}{l}\text { Ö̈̆rencile } \\
\text { rin yazılı } \\
\text { ürünleri } \\
\text { (Giriş } \\
\text { cümlesi } \\
\text { verilmiş) }\end{array}$ & $\begin{array}{l}\text { Kadınlar } \\
\text { erkeklerden } \\
\text { daha başarılı, } \\
\text { Lise ve } \\
\text { üniversite kendi } \\
\text { içerisinde } \\
\text { anlamlı farklılık } \\
\text { yok ama totalde } \\
\text { farklılık var. }\end{array}$ \\
\hline $\begin{array}{l}\text { 8. Sinıf } \\
\text { öğrencilerinin } \\
\text { yazma } \\
\text { taslakları } \\
\text { aracılığıyla } \\
\text { metin } \\
\text { tutarlıklarının } \\
\text { sağlanması: } \\
\text { bir eylem } \\
\text { araştırması }\end{array}$ & $\begin{array}{l}\text { Tok ve } \\
\text { Gönüla } \\
\text { l, } 2014\end{array}$ & $\begin{array}{l}\text { Geliştirilen } \\
\text { öğretim } \\
\text { etkinlikleri } \\
\text { ve yazma } \\
\text { öncesinde } \\
\text { hazırlanan } \\
\text { yazma } \\
\text { taslakları } \\
\text { aracılığıyla } \\
\text { 8. sinıf } \\
\text { öğrencilerin } \\
\text { in paragraf }\end{array}$ & $\begin{array}{l}\text { Eylem } \\
\text { Araştırm } \\
\text { ası }\end{array}$ & $\begin{array}{l}\text { 8. sinıf } \\
\text { ögrrenciler } \\
\text { i }\end{array}$ & $\begin{array}{l}14 \text { kadın, } \\
18 \text { erkek }\end{array}$ & $\begin{array}{l}\text { Eylem } \\
\text { planı, } \\
\text { öğrenci } \\
\text { ürünleri, } \\
\text { günlük, } \\
\text { görüssmel } \\
\text { er }\end{array}$ & $\begin{array}{l}\text { Uygulama, } \\
\text { öğrencilerin } \\
\text { yazılı } \\
\text { anlatımlarında } \\
\text { tutarlı metin } \\
\text { oluşturma, } \\
\text { uygun } \\
\text { destekleyici } \\
\text { unsurları bulma, } \\
\text { destekleyici } \\
\text { unsurların } \\
\text { artması, daha }\end{array}$ \\
\hline & $\begin{array}{r}\text { RumeliDE } L \\
\text { manağa Mal } \\
\mathrm{Ka} \\
\text { tel: }\end{array}$ & $\begin{array}{l}\text { il ve Edebiyat Ara } \\
\text { allesi, Mürver Çiç } \\
\text { lköy - İSTANBUL } \\
\text { e-posta: edit } \\
\text { +90 505 7958124, }\end{array}$ & $\begin{array}{r}\text { Adre } \\
\text { ttrmaları Dergi } \\
\text { i Sokak, No:14/ } \\
\text { TÜRKIYE } 3471 \\
\text { r@rumelide.cor } \\
90216773 \text { o } 61\end{array}$ & \multicolumn{4}{|c|}{\begin{tabular}{l|l} 
Address \\
RumeliDE Journal of Language and Literature Studies \\
Osmanağa Mahallesi, Mürver Ciceği Sokak, No:14/8 \\
Kadıöy - ISTANBUL/ TURKEY 34714 \\
e-mail: editor@rumelide.com, \\
phone: +90 505 7958124, +90 216773 o 616
\end{tabular}} \\
\hline
\end{tabular}


düzeyinde

metin

tutarlılıkları

nin

sağlanması

\begin{tabular}{|c|c|c|c|c|c|c|c|}
\hline $\begin{array}{l}\text { 7. Sinıf } \\
\text { ögrrencilerin } \\
\text { öyküleyici } \\
\text { metinlerinin } \\
\text { bağdaşıklı ve } \\
\text { tutarlılık } \\
\text { ölçütlerine } \\
\text { göre } \\
\text { değerlendiril } \\
\text { mesi }\end{array}$ & $\begin{array}{l}\text { Çoban } \\
\text { ve } \\
\text { Karad } \\
\text { üz, } \\
2015\end{array}$ & $\begin{array}{l}\begin{array}{l}\text { Sosyo- } \\
\text { ekonomik }\end{array} \\
\text { açıdan farklı } \\
\text { okullardaki } \\
\text { öğrencilerin } \\
\text { oluşturduğu } \\
\text { metinlerin } \\
\text { bağdaşıllk } \\
\text { ve tutarlılık } \\
\text { ölçütlerine } \\
\text { göre; } \\
\text { incelenmesi }\end{array}$ & $\begin{array}{l}\text { Nicel } \\
\text { yöntem }\end{array}$ & $\begin{array}{l}\text { 7. sinıf } \\
\text { ögrenciler } \\
\text { i }\end{array}$ & 83 öğrenci & $\begin{array}{l}\text { Öğrencile } \\
\text { rin yazılı } \\
\text { ürünleri } \\
\text { (Konu } \\
\text { verilmiş) }\end{array}$ & $\begin{array}{l}\text { Öğgrencilerin } \\
\text { bağdaşıklık ve } \\
\text { tutarlılık } \\
\text { puanları } \\
\text { bulundukları } \\
\text { sosyo-ekonomik } \\
\text { düzeye göre } \\
\text { farklılaşmamakt } \\
\text { adır. }\end{array}$ \\
\hline
\end{tabular}

Tablo 1 devamı...

\begin{tabular}{|c|c|c|c|c|c|c|c|}
\hline $\begin{array}{l}\text { Araştırmanı } \\
\text { n Adı }\end{array}$ & Yilı & Amaci & $\begin{array}{l}\text { Yönte } \\
\text { mi }\end{array}$ & $\begin{array}{l}\text { Örnekle } \\
\text { mi }\end{array}$ & $\begin{array}{l}\text { Katılımcil } \\
\text { ar }\end{array}$ & $\begin{array}{l}\text { Veri } \\
\text { Toplama } \\
\text { Araci }\end{array}$ & Sonuç \\
\hline $\begin{array}{l}\text { Türkçe } \\
\text { Öğretmen } \\
\text { Adaylarının } \\
\text { Metinlerinde } \\
\text { Tutarlılık }\end{array}$ & $\begin{array}{l}\text { Çoban } \\
\text { ve } \\
\text { Karadü } \\
\text { z, } 2016\end{array}$ & $\begin{array}{l}\text { Türkçe } \\
\text { öğretmen } \\
\text { adaylarının } \\
\text { oluşturdukla } \\
\text { rı hikâye } \\
\text { edici } \\
\text { metinlerin } \\
\text { tutarlılık } \\
\text { düzeyinin } \\
\text { belirlenmesi }\end{array}$ & $\begin{array}{l}\text { Nicel } \\
\text { yöntem }\end{array}$ & $\begin{array}{l}\text { Üniversite } \\
1 . \text { ve } 3 . \\
\text { sinif } \\
\text { öğrenciler } \\
\text { i }\end{array}$ & $\begin{array}{l}18 \\
\text { üniversite } \\
1 ., 17 \\
\text { üniversite } \\
3 . \text { sinıf - } 19 \\
\text { kız, } 16 \\
\text { erkek }\end{array}$ & $\begin{array}{l}\text { Öğrenciler } \\
\text { in yazılı } \\
\text { ürünleri } \\
\text { (Konu } \\
\text { verilmiş) }\end{array}$ & $\begin{array}{l}\text { Cinsiyet ve } \\
\text { sınıf } \\
\text { düzeyine } \\
\text { göre farklılık } \\
\text { yokken, } \\
\text { başarı } \\
\text { ortalaması } \\
\text { yüksek olan } \\
\text { öğrenciler } \\
\text { daha tutarlı } \\
\text { metinler } \\
\text { yazmışlardır. }\end{array}$ \\
\hline $\begin{array}{l}\text { Türkçe } \\
\text { öğretmeni } \\
\text { adaylarının } \\
\text { öyküleyici } \\
\text { anlatımlarının } \\
\text { bağdaşıklık ve } \\
\text { tutarlılık } \\
\text { açısından } \\
\text { incelenmesi }\end{array}$ & $\begin{array}{l}\text { Kalı, } \\
2016\end{array}$ & $\begin{array}{l}\text { Türkçe } \\
\text { öğretmeni } \\
\text { adayının } \\
\text { öyküleyici } \\
\text { metinlerini, } \\
\text { bağdaşılık } \\
\text { ve tutarlılık } \\
\text { unsurları } \\
\text { açısından } \\
\text { incelenmesi }\end{array}$ & $\begin{array}{l}\text { Nicel } \\
\text { yöntem }\end{array}$ & $\begin{array}{l}\text { Üniversite } \\
\text { 1. ve } 4 . \\
\text { sinif } \\
\text { öğrenciler } \\
\text { i }\end{array}$ & $\begin{array}{l}\text { 30 } \\
\text { üniversite } \\
\text { 1. sinıf, } 30 \\
\text { üniversite } \\
\text { 4. sinıf }\end{array}$ & $\begin{array}{l}\text { Öğgrenciler } \\
\text { in yazılı } \\
\text { ürünleri } \\
\text { (Öykü } \\
\text { girişi } \\
\text { verilmiş) }\end{array}$ & $\begin{array}{l}\text { Sinıf seviyesi } \\
\text { bağdaşılklık } \\
\text { faktöründe } \\
\text { anlamll } \\
\text { farklılık } \\
\text { gösterirken } \\
\text { tutarlık } \\
\text { faktöründe } \\
\text { anlamll } \\
\text { farklılık } \\
\text { görülmemişti } \\
\text { r. }\end{array}$ \\
\hline $\begin{array}{l}\text { Ortaokul } \\
\text { öğrencilerinin } \\
\text { yazılı } \\
\text { üretimlerinin } \\
\text { tutarlılık } \\
\text { ölçütlerine } \\
\text { göre } \\
\text { değerlendirilm } \\
\text { esi }\end{array}$ & $\begin{array}{l}\text { Dağaşa } \\
\mathrm{n}, 2018\end{array}$ & $\begin{array}{l}\text { Öğrencilerin } \\
\text { yazılı } \\
\text { ürünlerindek } \\
\text { i tutarlllık } \\
\text { düzeylerini } \\
\text { belirlemek }\end{array}$ & $\begin{array}{l}\text { Nitel } \\
\text { yöntem }\end{array}$ & $\begin{array}{l}\text { 6. sinıf } \\
\text { öğrenciler } \\
\text { i }\end{array}$ & 347 öğrenci & $\begin{array}{l}\text { Öğrenciler } \\
\text { in yazılı } \\
\text { ürünleri } \\
\text { (Konu } \\
\text { verilmiş) }\end{array}$ & $\begin{array}{l}\text { Sosyo- } \\
\text { ekonomik } \\
\text { düzeyi } \\
\text { yüksek olan } \\
\text { okulun } \\
\text { öğrencileri } \\
\text { daha tutarlı } \\
\text { metinler } \\
\text { yazmışlardır. }\end{array}$ \\
\hline 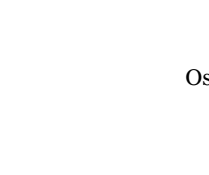 & $\begin{array}{r}\text { RumeliDE D } \\
\text { smanağa Mah } \\
\text { Kad } \\
\text { tel: }\end{array}$ & $\begin{array}{l}\text { ve Edebiyat Arasstu } \\
\text { lesi, Mürver Ciçeği } \\
\text { öy - İSTANBUL / T } \\
\text { e-posta: editor } \\
\text { o } 5057958124,+9\end{array}$ & $\begin{array}{r}\text { Adres } \\
\text { alart Dergisi } \\
\text { kak, No:14/8 } \\
\text { RKIYE } 34714 \\
\text { umelide.com } \\
216773 \text { o } 616\end{array}$ & \multicolumn{4}{|c|}{\begin{tabular}{|l} 
Address \\
RumeliDE Journal of Language and Literature Studies \\
Osmanağa Mahallesi, Mürver Çiçeği Sokak, No:14/8 \\
Kadıköy - ISTANBUL / TURKEY 34714 \\
e-mail: editor@rumelide.com, \\
phone: +90 505 7958124, +90 216773 o 616
\end{tabular}} \\
\hline
\end{tabular}




\begin{tabular}{|c|c|c|c|c|c|c|c|}
\hline $\begin{array}{l}\text { Ortaokul } 8 . \\
\text { sinıf } \\
\text { ögrrencilerinin } \\
\text { yaratıcı } \\
\text { metinlerinde } \\
\text { metinlerarasılı } \\
\text { k }\end{array}$ & $\begin{array}{l}\text { Güler, } \\
2018\end{array}$ & $\begin{array}{l}\text { Öğrencilerin } \\
\text { yaratıcı } \\
\text { yazma } \\
\text { çalışmalarıyl } \\
\text { a } \\
\text { oluşturdukla } \\
\text { rı metinlerin } \\
\text { metinlerarası } \\
\text { lık açısından } \\
\text { incelenmesi }\end{array}$ & $\begin{array}{l}\text { Nitel } \\
\text { yöntem }\end{array}$ & $\begin{array}{l}\text { 8. Sinıf } \\
\text { öğrenciler } \\
\text { i }\end{array}$ & $\begin{array}{l}30 \text { alt, } 30 \\
\text { orta, } 30 \text { üst } \\
\text { sosyo- } \\
\text { ekonomik } \\
\text { düzey }\end{array}$ & $\begin{array}{l}\text { Öğrenciler } \\
\text { in yazılı } \\
\text { ürünleri } \\
\text { (Konu } \\
\text { verilmiş) }\end{array}$ & $\begin{array}{l}\text { Metinlerarası } \\
\text { llk } \\
\text { ölçütlerinin } \\
\text { kullanım } \\
\text { slklığının } \\
\text { sosyoekonom } \\
\text { ik düzeyle } \\
\text { doğru } \\
\text { orantılı } \\
\text { olduğu } \\
\text { görülmüştür. }\end{array}$ \\
\hline $\begin{array}{l}\text { İşiten ve } \\
\text { işitme } \\
\text { yetersizliği } \\
\text { olan } \\
\text { öğrencilerin } \\
\text { özetleme } \\
\text { becerilerinin } \\
\text { karşılaştırmalı } \\
\text { olarak } \\
\text { incelenmesi }\end{array}$ & $\begin{array}{l}\text { Sümer } \\
\text { ve } \\
\text { Turna, } \\
2019\end{array}$ & $\begin{array}{l}\text { İşiten ve } \\
\text { işitme } \\
\text { yetersizliği } \\
\text { olan } \\
\text { öğrencilerin } \\
\text { özetleme } \\
\text { becerileri ve } \\
\text { bağdaşılklı } \\
\text { düzeylerinin } \\
\text { incelenmesi }\end{array}$ & $\begin{array}{l}\text { Nicel } \\
\text { yöntem }\end{array}$ & $\begin{array}{l}\text { 8. sinıf } \\
\text { öğrenciler } \\
\mathrm{i}\end{array}$ & $\begin{array}{l}15 \text { işitme } \\
\text { yetersizliği, } \\
15 \text { normal } \\
\text { gelişim } \\
\text { gösteren } \\
\text { öğrenci }\end{array}$ & $\begin{array}{l}\text { Metin } \\
\text { verilmiş } \\
\text { ve } \\
\text { özetlemele } \\
\text { ri istenmiş }\end{array}$ & $\begin{array}{l}\text { Bağdaş̧ılık } \\
\text { araçlarının } \\
\text { kullanımında } \\
\text { normal } \\
\text { gelişim } \\
\text { gösteren } \\
\text { bireylerin } \\
\text { lehine } \\
\text { anlamlı } \\
\text { farklılık } \\
\text { bulunmuştur } \\
\text {. }\end{array}$ \\
\hline
\end{tabular}

Tablo 1 devamı...

\begin{tabular}{|c|c|c|c|c|c|c|c|}
\hline $\begin{array}{l}\text { Araştırmanı } \\
\text { n Adı }\end{array}$ & Yilı & Amaci & $\begin{array}{l}\text { Yönte } \\
\text { mi }\end{array}$ & $\begin{array}{l}\text { Örnekle } \\
\text { mi }\end{array}$ & $\begin{array}{l}\text { Katılımcil } \\
\text { ar }\end{array}$ & $\begin{array}{l}\text { Veri } \\
\text { Toplama } \\
\text { Araci }\end{array}$ & Sonuç \\
\hline $\begin{array}{l}\text { Metinlerarasılı } \\
\text { ğın Türkçe } \\
\text { öğretiminde } \\
\text { kullanımına } \\
\text { yönelik bir } \\
\text { eylem } \\
\text { araştırması: } 7 \text {. } \\
\text { sınıf örneği }\end{array}$ & $\begin{array}{l}\text { Tutkun } \\
\text {, } 2019\end{array}$ & $\begin{array}{l}\text { Mevcut } \\
\text { öğretim } \\
\text { sürecini } \\
\text { metinlerarası } \\
\text { lık kuramına } \\
\text { göre yeniden } \\
\text { yapılandırara } \\
\text { k } \\
\text { öğrencilerin } \\
\text { üst düzey } \\
\text { bilişsel } \\
\text { süreçleri } \\
\text { kullanarak } \\
\text { metinler } \\
\text { arası anlam } \\
\text { kurmalarını } \\
\text { ve metinler } \\
\text { arası } \\
\text { düşünmeleri } \\
\text { geliştirmek }\end{array}$ & $\begin{array}{l}\text { Nitel } \\
\text { yöntem }\end{array}$ & $\begin{array}{l}\text { 7. sinıf } \\
\text { öğrenciler } \\
\text { i }\end{array}$ & $26 \mathrm{klz}$ & $\begin{array}{l}\text { Örnek } \\
\text { metinler, } \\
\text { metinlerin } \\
\text { ö ğrenciler } \\
\text { tarafindan } \\
\text { yeniden } \\
\text { oluşturulm } \\
\text { ası }\end{array}$ & $\begin{array}{l}\text { Metinlerarası } \\
\text { lık kuramına } \\
\text { bağlı olarak } \\
\text { yapılandırılm } \\
\text { ış öğretim } \\
\text { sürecinde } \\
\text { öğrencilerin } \\
\text { üst düzey } \\
\text { bilişsel } \\
\text { süreçleri } \\
\text { daha fazla } \\
\text { kullandıkları, } \\
\text { metinler } \\
\text { arası anlam } \\
\text { kurmada ve } \\
\text { metinler } \\
\text { arası } \\
\text { düşünmede } \\
\text { süreç içinde } \\
\text { anlamlı bir } \\
\text { değişim } \\
\text { olduğu } \\
\text { belirlenmişti } \\
\text { r }\end{array}$ \\
\hline $\begin{array}{l}\text { Metin türleri } \\
\text { bağlamında az } \\
\text { gören, görme } \\
\text { engelli ve } \\
\text { gören } \\
\text { öğrencilerin } \\
\text { yazılı ifade }\end{array}$ & $\begin{array}{l}\text { Aslan } \\
\text { ve } \\
\text { Çakma } \\
\text { k, } \\
2020\end{array}$ & $\begin{array}{l}\text { Metin türleri } \\
\text { bağlamında } \\
\text { az gören, } \\
\text { görme } \\
\text { engelli ve } \\
\text { gören } \\
\text { öğrencilerin } \\
\text { yazılı ifade }\end{array}$ & $\begin{array}{l}\text { Nicel } \\
\text { yöntem }\end{array}$ & $\begin{array}{l}\text { 5., 6., 7., } \\
\text { 8. sinıf } \\
\text { öğrenciler } \\
\text { i }\end{array}$ & $\begin{array}{l}111 \text { az } \\
\text { gören, } 113 \\
\text { görme } \\
\text { engelli, } 120 \\
\text { gören } \\
\text { öğrenci / } \\
158 \text { kadın, } \\
186 \text { erkek }\end{array}$ & $\begin{array}{l}\text { Öğrencileri } \\
\text { n yazdıkları } \\
\text { anı, ikna } \\
\text { edici ve } \\
\text { bilgilendiri } \\
\text { ci metinler }\end{array}$ & $\begin{array}{l}\text { Metin } \\
\text { türlerine } \\
\text { göre } \\
\text { tutarlılıkta ve } \\
\text { bağdaşıklıkta } \\
\text { anlamlı } \\
\text { farklılıklar } \\
\text { vardır. }\end{array}$ \\
\hline & $\begin{array}{r}\text { KameliDE } D \\
\text { lanağa Mah } \\
\text { tel: }+\end{array}$ & $\begin{array}{l}\text { ve Edebiyat Araştı } \\
\text { lesi, Mürver Çiçĕg } \\
\text { öy - İTANBUL / T } \\
\text { e-posta: editor } \\
\text { O-po5 7958124, +9 }\end{array}$ & $\begin{array}{r}\text { Adres } \\
\text { alarl Dergisi } \\
\text { kak, No:14/8 } \\
\text { RKIYE } 34714 \\
\text { umelide.com } \\
216773 \text { o } 616\end{array}$ & \multicolumn{4}{|c|}{\begin{tabular}{|l} 
Address \\
RumeliDE Journal of Language and Literature Studies \\
Osmanağa Mahallesi, Mürver Ciçeği Sokak, No:14/8 \\
Kadıköy - ISTANBUL / TURKEY 34714 \\
e-mail: editor@rumelide.com, \\
phone: +90 505 7958124, +90 216773 o 616
\end{tabular}} \\
\hline
\end{tabular}


becerilerinin becerilerinin

incelenmesi incelenmesi

Araştırmaların katılımcılarına baktığımızda toplam katılımcı sayısının 5305 kişi olduğu, cinsiyete yönelik dağılıma baktığımızda ise 1960 katılımcının kız, 1923 katılımcının erkek ve 1422 katılımcının cinsiyetinin belirtilmediği görülmektedir. Cinsiyet faktörünün sinıf seviyesine göre dağllımına bakıldığında ise ikinci sınıfa devam eden 144 öğrenci, beşinci sınıfa devam eden 520 öğrenci, altıncı sınıfa devem eden 431 öğrenci, yedinci sınıfa devam eden 227 öğrenci, sekizinci sınıfa devam eden 455 öğrenci, dokuzuncu sınıfa devem eden 282 öğrenci, onuncu sınıfa devam eden 262 öğrenci, on birinci sinıfa devam eden 2270 öğrenci, on ikinci sinıfa devam eden 24 öğrenci, üniversite birinci sınıfa devam eden 48 öğrenci, üniversite üçüncü sınıfa devam eden 42 öğrenci, üniversite dördüncü sınıfa devam eden 63 öğrenci olduğu görülmektedir. Ayrıca araştırmalarda dikkat çeken bir diğer konu da iki çalışmanın katılımcılarının yetersizliği olan öğrencilerden oluşmasıdır. Sümer ve Turna (2019), çalışmalarında işitme yetersizliği olan 15 öğrencinin bağdaşıklık ve tutarlılıklarını işitme yetersizlĭgi olmayan öğrenciler ile karşılaştırmışlardır. Yine Aslan ve Çakmak (2020), ortaokula devam eden 113 görme yetersizliği olan, 111 az gören ve 120 normal gelişim gösteren öğrencinin yazılı ürünlerini farklı metin türlerinde bağdaşıklık ve tutarlılık açısından değerlendirmiştir.

İncelenen araştırmalarda verilerin toplanması kısmında izlenen yöntemlere bakıldığında; araştırmaların 13 tanesinde öğrencilere konu verilerek yazdıkları ürünlerin incelenmesi (Keçik, 1992; Coşkun, 2005; Çeçen, 2011; Coşkun, 2011; Ülper, 2011; Can, 2012; Yılmaz, 2012; Keklik ve Yılmaz, 2013; Çoban ve Karadüz, 2015; Çoban ve Karadüz, 2016; Dağaşan, 2018; Güler, 2018; Aslan ve Çakmak, 2020), müdahale programı oluşturulmuş, öğrencilere bağdaşıklı öğelerini kullanma ve tutarlı metinler oluşturma çalışması (Tok ve Gönülal, 2014; Tutkun, 2019), iki araştırmada üç cümlelik bir giriş verilmiş ve öğrencilerden metni tamamlamaları istenmiş (Seçkin, Arslan ve Ergenç, 2014; Kalı, 2016), iki araştırmada herhangi bir konu verilmediği (Göçer, 2010; Göçer, 2012) ve bir araştırmada ise okunulan metnin özetlenmesi istenerek yazılan ürünlerin incelemesi (Sümer ve Turna, 2019) yapılmıştır.

Araştırmaların bulgularını değerlendirdiğimizde, incelenen metinsellik ölçütlerinin çeşitli sınıf seviyelerini inceleyen 3 araştırmada sınıf seviyeleri arasında anlamlı farklılık gösterdiği (Coşkun, 2005; Ülper, 2011; Yılmaz, 2012), 3 araştırmada ise sınıf seviyeleri arasında anlamlı bir farklılık olmadığı (Keçik, 1992; Can, 2012; Çoban ve Karadüz, 2016) görülmektedir. Aynı sınıf seviyesindeki öğrencilerin farklı değişkenler (cinsiyet, sosyo-ekonomik durum vb.) açısından incelendiği araştırmaların 3 tanesinde (Dağaşan, 2018; Güler, 2018; Sümer ve Turna,2019) çeşitli değişkenlerin öğrencilerin kullandıkları metinsellik öğelerinin sıklığını etkilediğini, 3 tanesinde ise (Coşkun, 2011, Çoban ve Karadüz, 2015; Kal, 2016) incelenen değişkenlerin öğrencilerin metinsellik öğelerini kullanma sıklığına herhangi bir etkisinin olmadığıbelirtmektedir. Müdahale içeren araştırmalara bakıldığında (Tok ve Gönülal, 2014; Tutkun, 2019) uygulanan programların etkili olduğunu ve çalışmalara katılan öğrencilerin müdahaleler sonrasında metinsellik öğelerini kullanma sıklı̆ının arttığını belirtmişlerdir. Yalnızca kullanılan ölçeklerin puanlamalarına ilişkin bilgi veren 4 araştırmada (Göçer, 2010; Çeçen, 2011; Göçer, 2012; Keklik ve Yılmaz, 2013) öğrencilerin yazılı anlatımlarında incelenen metinsellik öğelerinin orta düzeyde kullanıldığına ilişkin bilgi verilmektedir.

\section{Sonuç, tartışma ve öneriler}

Öğrencilerce üretilen yazılı metinlerin metinsellik özellikleri açısından incelendiği araştırmalara yönelik olarak yapılan bu çalışmada alanyazın taraması sonrası elde edilen 83 araştırmanın 22'si yer almıştır.

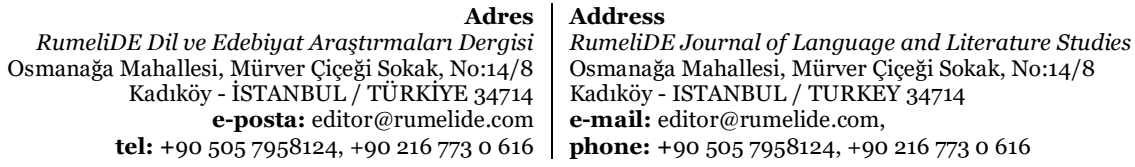


Alanyazında yapılan araştırmaların çoğu ders kitapları ya da uzmanlar/yazarlar tarafından yazılan metinleri incelemeye yöneliktir. Bu durumun öğrencilerle yapılan çalışmaların bireysel becerileri yansıtmasından ve ileriki dönem literatüründe yer almayacağı konusunun göz önünde bulundurulmasından kaynaklandığı düşünülmektedir. Yani, nitelikli bir metin ortaya koymanın yolunun metin oluşturmanın öğretiminden geçeceği düşüncesi göz ardı edilmiştir. Halbuki Crossley ve McNamara (2010), okul yaşantısının ilk yllarının nitelikli bir metin ortaya koymak için çok önemli olduğunu belirtmişlerdir. Yine alan yazında metin öğretimi ve yazılı anlatımın öğretimine yönelik çalışmaların öğrencilerin yazılı anlatım becerilerine katkı sağladığı görülmektedir (Güzel, 1999; Coşkun, 2005; Öztürk, 2016).

Çalışmanın dikkat çeken bir diğer bulgusu da incelenen araştırmalarda metinsellik ölçütlerinden "bağdaşıklık, tutarlılık ve metinler arasılık" öğelerinin çok araştırıldığı "amaçlılık, kabul edilebilirlik, bilgilendiricilik, duruma uygun olma” öğelerine ise hiçbir araştırmada yer verilmediğidir. Yapılan taramalarda ve araştırmaların literatür kısımlarına bakıldığında özellikle bağdaşıklık ve tutarlılığa diğer öğelerden daha fazla yer verildiği görülmektedir. Bunun ilgili alanyazında bağdaşıklık ve tutarlılığın metinsellik ölçütlerinin temellerini oluşturduğu ve diğer öğeleri kapsadığı düşüncesinden kaynaklı olduğu düşünülmektedir (Coşkun, 2005; Karatay, 2010; Yllmaz, 2012; Dağaşan, 2018). Carretti, Re ve Arfe (2013) ise yukarıdaki durumun aksine metinsellik ölçütlerinin birbirleriyle iç içe geçmiş olduklarını ancak hepsinin kendi içlerinde bağımsız olduklarını ve birbirlerini kapmadıklarını dile getirmişlerdir.

Çalışmanın katılımcılarına ilişkin, en sık ortaokul öğrencileriyle ve sınıflar arası karşılaştırmalar konusunda yapılmış olması dikkat çekmektedir. Milli Eğitim Bakanlığı'nın (MEB) 2019 yılında hazırlamış olduğu Türkçe dersi müfredatında metinsellik ölçütlerinin kazanımlar arasında altıncı sınıftan itibaren yer almaya başlamış olmasının yapılan araştırmalara yön vermiş olduğu düşünülmektedir. Ayrıca ilkokulun ilk yıllarının okuma, okuduğunu anlama ve temel yazma eğitimlerini barındırması öğrencilerin yazılı anlatım becerilerinin bu seviyede olması metinsellik ölçütlerinin bu dönemlerde değerlendirilmemesini açıklar niteliktedir (Güneş, 2013). Çalışmanın katılımcılara yönelik bulgularından bir diğeri ise yapılan araştırmaların bir kısmının lisans öğrencileri ile yapılmış olması ve katılımcıların Türkçe ya da Sınıf öğretmenliği alanında eğitim alan öğrencilerden oluşmasıdır. Bu durumun araştırmacıların çocukların geleceğine yön verecek olan öğretmen adaylarının metinsellik ölçütleri öğretimine yönelik olarak ne kadar iyi bir eğitim almışlarsa, meslek hayatlarında verecekleri dil eğitiminin de o kadar iyi olacağı düşüncesinden kaynaklandığı görülmektedir (Göçer, 2010; Ülper, 2011; Seçkin, Aslan ve Ergenç, 2014; Çoban ve Karadüz; 2016). Katılımcılara ilişkin dikkat çeken bir diğer bulgu ise, uluslararası alanyazında özel gereksinimli olan öğrencilerin yazılı ürünlerinin metinsellik öğeleri açısından incelendiği görülürken ülkemizde özel gereksinimli öğrencilerin katılımcı olduğu yalnızca iki çalışma vardır.

Çalışmada, çoğunlukla öğrencilerin sınıf seviyelerine göre kullandıkları metinsellik ölçütlerinin sıklığının karşılaştıııldığı görülmektedir. Bu durumun öğrencilerin zihinsel gelişimlerinin ve yazma deneyimlerinin artmasının kullanılan metinsellik ölçütlerine etkisinin araştırılmak istenmesiyle ilişkili olabileceği düşünülmektedir. Alanyazında yapılmış çalışmaların çoğunluğu, sınıf seviyesinin ilerlemesi ile metinsellik ölçütlerinin kullanım sıklı̆̆ının arttığını belirtmektedir (Coşkun; 2005; Ülper, 2011; Can, 2012; Lucero, Fernandez ve Montanero, 2018). Ancak bu bulgunun tam tersi olan sinif seviyesinin metinsellik ölçütlerinin kullanım sıklığına herhangi bir etkisi olmadığını ortaya koyan çalışmalar da yer almaktadır (Keçik, 1992; Çoban ve Karadüz, 2016; Seçkin, Aslan ve Ergenç, 2014; Kalı, 2016).

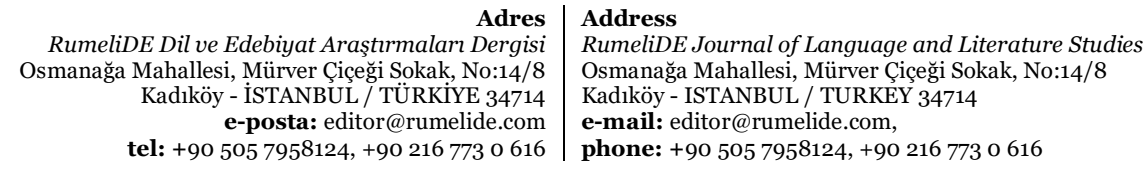


Metinsellik ölçütlerinin öğrencilerin yazılı ürünlerinde yer aldığı bu literatür taramasında bazı sınırlılıklar ve bu sınırlılıklar çerçevesinde öneriler bulunmaktadır. Çalışmanın sinırlılıklarından ilki yalnızca ülkemizde yapılmış araştırmaları içermesidir, ilerideki araştırmalara öneri olarak uluslararası literatürün incelenmesi tavsiye edilmektedir. Çalışma, öğrencilerin yazılı anlatımlarındaki metinsellik ölçütlerinin incelenmesiyle sınılıdır, öğrencilerin yada bireylerin sözlü anlatım becerilerinin metinsellik ölçütleri bağlamında araştırılması tavsiye edilmektedir. Çalışmada uygulama içeren yalnızca bir çalışma olması bu alanda uygulama içeren araştırmalara ihtiyaç duyulduğunu göstermektedir. Dolayısıyla ileride bu yönde araştırmaların yapılması önerilmektedir. İncelenen araştırmaların çoğunlukla az sayıda katılımcıyla ve özel gereksinimi olan öğrencilere çok az yer verilerek yürütüldüğü görülmektedir. Bundan dolayı ileriki araştırmaların daha fazla katılımcıyla ve özel gereksinimi olan öğrencileri de barındırarak yürütülmesi tavsiye edilmektedir. Uygulamalara yönelik olarak ise; öğrencilerin yaratıı yazma becerilerini destekleyen etkinliklere daha fazla yer verilmesi, öğrencilerin metinsellik ölçütlerini kavramaları için etkili öğretimlerin yapılması ve okunan metinlerin metinsellik ölçütleri kapsamında değerlendirilmesinin öğrencilere öğretilmesi önerilmektedir.

\section{Kaynakça}

Akçay, A. ve Şahin, N. (2015). Türk Dilinin Eski Yazılı Örneklerinin Ortaokul Türkçe Ders Kitaplarında Metin Olarak Yer Alabilirliğinin İncelenmesi. Uluslararası Eğitim Bilim ve Teknoloji Dergisi, 1(1), 53-64.

Aksu, S. (2020). Bağdaşıklık Üzerine Bir Bibliyografya Denemesi. Uluslararası Beşeri Bilimler ve Eğitim Dergisi, 6(13), 412-445.

Aslan, C. ve Çakmak, S. (2020). Metin Türleri Bağlamında Az Gören, Görme Engelli ve Gören Öğrencilerin Yazılı İfade Becerilerinin İncelenmesi. Ana Dili Eğitimi Dergisi, 8(3), 868-885.

Bae, J. (2001). Cohesion And Coherence in Children's Written English: Immersion and English-Only Classes. Issues in Applied Linguistics. 12(1), 51-88.

Berninger, V. W. ve Abbott, R. D. (2010). Listening Comprehension, Oral Expression, Reading Comprehension, and Written Expression: Related Yet Unique Language Systems in Grades 1, 3, 5, and 7. Journal of Educational Psychology, 12(3), 635-651.

Beyreli, L., Çetindağ, Z. ve Celepoğlu, A. (2005). Yazıl ve Sözlü Anlatım. (1. Baskı) Ankara: Pegem Yayıncilık.

Bozok, L. (2019). "Ortaokul 8. Sınıf Türkçe Ders Kitaplarındaki Metinlerin Bağdaşıklık ve Tutarlılık Yönünden İncelenmesi”. Yayımlanmamış Yüksek Lisans Tezi. Hatay: Mustafa Kemal Üniversitesi Sosyal Bilimler Enstitüsü.

Can, R. (2012). “Ortaöğretim Öğrencilerinin Yazılı Anlatımlarında Paragraf Düzeyinde Bağdaşıklık Ve Tutarlılık”. Yayımlanmamış Doktora Tezi. Ankara: Gazi Üniversitesi Eğitim Bilimleri Enstitüsü.

Carretti, B., Re, A. M. ve Arfe, B. (2013). Reading Comprehension And Expressive Writing: A Comparison Between Good And Poor Comprehenders. Journal of Learning Disabilities, 46(1), 87-96.

Çeçen, M. A. (2011). Yedinci Sınıf Öğrencilerinin Öyküleyici Yazılarında Tutarlılık. Türkiye Sosyal Araştırmalar Dergisi, 15(2), 67-87.

Çoban, A. ve Karadüz, A. (2015). 7. Sinıf Öğrencilerin Öyküleyici Metinlerinin Bağdaşıklık Ve Tutarlılık Ölçütlerine Göre Değerlendirilmesi. Adıyaman Üniversitesi Sosyal Bilimler Enstitüsü Dergisi, 19, 67-96.

Çoban, A. ve Karadüz, A. (2016). Türkçe Öğretmen Adaylarının Metinlerinde Tutarlılık. Uluslararası Türkçe Ĕ̆itimi ve Öğretimi Dergisi: Kuram ve Uygulama, 1(1), 131-141.

Coşkun, E. (2005). İlköğretim öğrencilerinin öyküleyici anlatımlarında bağdaşıklk, tutarlılıve metin elementleri. Yayımlanmamış Doktora Tezi. Ankara: Gazi Üniversitesi Eğitim Bilimleri Enstitüsü.

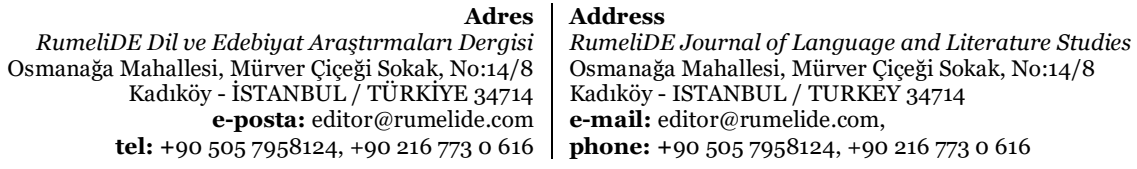


Coşkun, E. (2008). İlköğretim öğrencilerinin öyküleyici anlatımlarında metin tutarlılığı. XXI. Ulusal Dilbilim Kurultayı (10-11 Mayıs 2007) Bildirileri, 251-260.

Coşkun, E. (2011). Türk ve göçmen öğrencilerin yazılı anlatımlarında metin bağdaşıklı̆̆ı. Kuram ve Uygulamada Ĕ̆itim Bilimleri, 11(2), 881-899.

Crossley, S. A. ve McNamara, D. S. (2010). Say more and be more coherent: how text elaboration and cohesion can increase writing quality. Grantee Submission, 7(3), 351-370.

Çalık, M. ve Sözbilir, M. (2014). İçerik analizinin parametreleri. Eğitim ve Bilim, 39(174), 33-38.

Dağaşan, R. (2018). Ortaokul öğrencilerinin yazıl üretimlerinin tutarlılk _ölçütlerine göre değerlendirilmesi. Yayımlanmamış Yüksek Lisans Tezi. Kırıkkale: Kırıkkale Üniversitesi Sosyal Bilimler Enstitüsü.

De Beaugrande, R. ve Dressler, W. (1981). Introduction to text linguistics. London \& New York: Longman.

Frankel,R. M., \& Devers, K.J.(2000). Study design in qualitative research - 1: Developing questions and assessing resource needs. Education for Health, 13(2), 251-261.

Göçer, A. (2010). Eğitim fakültesi öğrencilerinin yazılı anlatım becerilerinin süreç yaklaşımı ve metinsellik ölçütleri ekseninde değerlendirilmesi niğde üniversitesi örneği. Kastamonu Ĕ̆itim Dergisi, 18(1), 271-290.

Göçer, A. (2012). Türkçe öğretmen adaylarının yetizleme çalışmalarıyla oluşturdukları metinlerin metinlerarasılık: dilsel metinlerin kullanımı açısından incelenmesi. International Online Journal of Educational Sciences, 4(1), 184-195.

Güler, V. (2018). Ortaokul 8. sinıf öğrencilerinin yaratıcı metinlerinde metinlerarasılı. Yayımlanmamış Yüksek Lisans Tezi. Elazığ: Fırat Üniversitesi Eğitim Bilimleri Enstitüsü.

Günay, V. D. (2001). Metin Bilgisi, İstanbul: Multilingual.

Güneş, F. (2013). Türkçe öğretimi, Ankara: Pegem Akademi.

Güven, A. Z. (2014). Mustafa Kutlu'nun hikâyelerinde bağdaşıklık ve tutarlılık. International Journal of Language Academy Volume, 2(4), 599-609.

Güzel-Özmen, R. (1999). Öykü yapısı ve öykü yapısının okuduğunu anlama öğretiminde kullanılması. Bilig Türk Dünyası Sosyal Bilimler Dergisi, 11, 105-119.

Halliday, M. ve Hasan, R. (1976). Cohesion in English. New York: Longman Group UK Limited.

Kall, G. (2016). Türkçe öğretmeni adaylarının öyküleyici anlatımlarının bağdaşıklık ve tutarlılık açısından incelenmesi. Yayımlanmamış Yüksek Lisans Tezi. Muğla: Muğla Sitkı Kocaman Üniversitesi Eğitim Bilimleri Enstitüsü.

Karaağaç, G. (2013). Dil Bilimi Terimleri Sözlüğü. Ankara: Türk Dil Kurumu Yayınları.

Karakuş, N., Deniz, B. ve Karayazı, N. (2018). 1938 okuma kitabı ve 2017 Türkçe ders kitabının metinsellik ölçütleri yönünden karşlaştırmalı değerlendirmesi. Ders Kitapları Uluslararası Sempozyumu, İstanbul.

Karatay, H. (2010). İlköğretim öğrencilerinin okuduğunu kavrama ile ilgili bilişsel farkındalıkları. Journal of Türklük Bilimi Arastirmalari, 27, 457-475.

Keçik, İ. (1992). İlkokul öğrencilerinin özet ve hatırlama metinlerinde bağdaşıklık sorunu. Dilbilim Araştırmaları Dergisi, 3, 71-75.

Keklik, S. ve Yılmaz, Ö. (2013). 11. sınıf öğrencilerine ait öyküleyici metinlerin bağdaşıklık ve tutarlılık açısından incelenmesi. Uşak Üniversitesi Sosyal Bilimler Dergisi, 4(4), 139-157.

Lüleci, M. (2010). Yeni bir disiplin olarak metin dilbilim ve Türk edebiyatına metin dilbilimsel bir yaklaşım. Yayınlanmamış Doktora Tezi. Ankara: Gazi Üniversitesi Eğitim Bilimleri Enstitüsü.

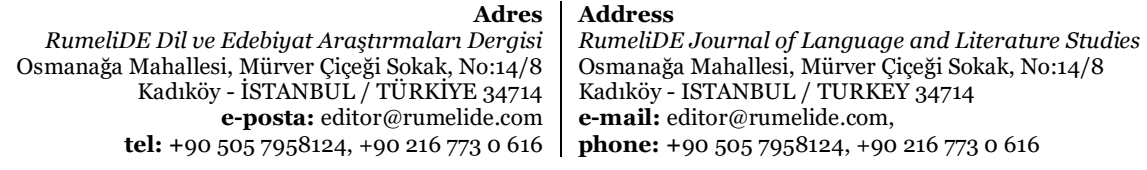


Öztürk, H. (2016). Öğrenme güçlüğü olan çocuklarm öyküleme yoluyla ölçümlenen yazıl ifadeleri ve yazma kaygıları arasındaki ilişki. Yayımlanmamış Yüksek Lisans Tezi. İzmir: Dokuz Eylül Üniversitesi, Eğitim Bilimleri Enstütüsü.

Seçkin, P., Arslan, N. ve Ergenç, S. (2014). Bağdaşıklık ve tutarlılık bakımından lise ve üniversite öğrencilerinin yazllı anlatım becerileri. Uluslararası Türkçe Edebiyat Kültür Eğitim (TEKE) Dergisi, 3(1), 340-353.

Senechall, M., Hill, S. ve Malette, M. (2018). Individual differences in grade 4 children's written compositions: the role of online planning and revising, oral storytelling, and reading for pleasure. Cognitive Development, 45, 92-104.

Sümer, H. M. ve Turna, C. (2018). İşiten ve işitme yetersizliği olan öğrencilerin özetleme becerileri açısından incelenmesi. Ankara Üniversitesi Ĕ̆itim Bilimleri Fakültesi Özel Eğitim Dergisi, 19(3), 531-551.

Tok, M. ve Gönülal, M. (2014). 8. sınıf öğrencilerinin yazma taslakları aracıllğıyla metin tutarlıklarının sağlanması: Bir eylem araştırması. Electronic Turkish Studies, 9(6), 1025-1021.

Tutkun, Y. (2019). Metinlerarasılı̆ın Türkçe öğretiminde kullanımına yönelik bir eylem araştırması: 7. sinıf örneği. Yayımlanmamış Yüksek Lisans Tezi. İstanbul: Sosyal Bilimler Enstitüsü.

Ülper, H. (2011). Öğrenci metinlerinin tutarlılık ölçütleri bağlamında değerlendirilmesi. Turkish Studies (Elektronik), 6(4), 849-863.

Wei-Dong, G. (2008). Informational segmentation and text coherence. US-China Foreign Language, 6(3), 7-10.

Westwood, P. (2008). What Teachers Need to Know About Reading and Writing Difficulties, Aust Council for Ed Research.

Yelboğa, A., \& Tavşancll, E. (2010). The Examination of Reliability According to Classical Test and Generalizability on a Job Performance Scale. Educational Sciences: Theory and Practice, 10(3), 1847-1854.

Yıldırım, A. ve Şimşek, H. (2011). Sosyal Bilimlerde Nitel Araştırma Yöntemleri. Ankara: Seçkin.

Yılmaz, Ö. (2012). 11. sınıf öğrencilerine ait öyküleyici metinlerin bağdaşıklk ve tutarlılkk açısından incelenmesi. Yayımlanmamış Yüksek Lisans Tezi. Zonguldak: Bülent Ecevit Üniversitesi Sosyal Bilimler Enstitüsü.

RumeliDE Dil ve Edebiyat Araştırmaları Dergisi Osmanağa Mahallesi, Mürver Çiçeği Sokak, No:14/8 Kadıköy - İSTANBUL / TÜRKIYE 34714 e-posta: editor@rumelide.com tel: +90 $5057958124,+902167730616$
Address

RumeliDE Journal of Language and Literature Studies

Osmanağa Mahallesi, Mürver Çiçeği Sokak, No:14/8

Kadıköy - ISTANBUL / TURKEY 34714

e-mail: editor@rumelide.com,

phone: +90 $5057958124,+902167730616$ 